\title{
Methane Concentration in Water Column and in Pore Water of a Coastal Lagoon (Cabiúnas Lagoon, Macaé, RJ, Brazil)
}

\author{
André Luiz dos Santos Fonseca*, Murilo Minello, Claudio Cardoso Marinho and Francisco \\ de Assis Esteves \\ Laboratório de Limnologia; Departamento de Ecologia; Instituto de Biologia; CCS; Cidade Universitária; UFRJ; \\ 21941-590; C. P. 68020; afonseca@biologia.ufrj.br; Rio de Janeiro - RJ - Brazil
}

\begin{abstract}
The aim of this study was to evaluate methane concentration in water column and pore water at limnetic and littoral regions of a coastal lagoon. At the littoral region samples were taken from three monospecific macrophytes stands (Typha domingensis, Eleocharis interstincta and Potamogeton stenostachys). The methane concentration in the pore water at the littoral region was higher than the concentration found at the limnetic region in each fraction of the sediment. The higher methane concentration in the superficial fraction of the sediment $(0-2 \mathrm{~cm})$ was shown at the $P$. stenostachys stand $(3.7 \mathrm{mM})$. It was the only significantly different $(p<0.05)$ from the limnetic region. The pore water methane concentration increased with depth at the aquatic macrophytes stands. The methane concentration in the water column did not vary significantly among the sampling sites ( $p>0.05)$. It could be concluded that there was a high influence of aquatic macrophytes on the pore water methane concentration.
\end{abstract}

Key words: Methane, water column, sediment, aquatic macrophytes, coastal lagoons

\section{INTRODUCTION}

Methanogens are strictly anaerobic microorganisms that produce methane as the final product of their metabolism. Their most common habitats are freshwater and saline sediments, the digestive tract of animals and anaerobic digesters (Jones, 1991). The importance of methanogens in carbon cycling has been widely known (Boone, 1991). At aquatic ecosystems, the sediment is the main site of methanogenesis so, when the water column is anaerobic, it can support a significant methanogenesis (Kiene, 1991). Methanogens can use a short amount of substrates, mainly acetate, formate and hydrogen (Fenchel et al., 1998, Segers and Kengen, 1998). Hence, the conversion of many organic molecules into methane needs interactions between non-methanogenic organisms and methanogens. The former can use a great variety of organic molecules that result in final metabolic products, which can be used by methanogens, resulting in methane production (Boone, 1991).

The majority of the coastal aquatic tropical ecosystems are shallow, allowing a wide development of aquatic macrophytes (Esteves, 1998). The aquatic macrophytes influence directly on methane dynamics at wetlands, once they are source of organic matter to the methanogens (Neue et al., 1997). The organic matter from aquatic

\footnotetext{
* Author for correspondence
} 
macrophytes can be more resistant to decomposition, like the one from the emergent aquatic macrophytes Typha domingensis Pers. and Eleocharis fistulosa Schult., which have most of their carbon in support tissues. Otherwise, it can be more labile like the one from Potamogeton stenostachys $\mathrm{K}$. Schum, a submergent aquatic macrophyte (Farjalla et al., 1999). Aquatic macrophytes can also act as a route to release methane to the atmosphere, through the aerenchyma (Boon and Sorrell, 1995, Kulshreshtha et al., 2000, Yavitt and Knapp, 1995), but it can also be released from the sediment to the atmosphere through diffusion of dissolved methane and ebullition of gas bubbles (Neue et al., 1997). The aquatic macrophytes play an important role in methane oxidation because their roots and rhizomes promote the sediment oxygenation, which allows the development of methanotrophic bacteria responsible for the oxidation of $\mathrm{CH}_{4}$ into $\mathrm{CO}_{2}$ (King, 1994).

The wetlands are considered the main source of atmospheric methane (Cicerone and Oremland, 1988) that currently contributes with about $20 \%$ to the global warming effect (Neue et al., 1997), because of its capacity to absorb infrared radiation. Considering the role of aquatic macrophytes community to the methane dynamics in wetlands, it is of great importance to study the influences of this community upon the methane biogeochemical processes at coastal aquatic tropical ecosystems. The alarming global changes attributed to methane, have raised questions about how these changes had already affected the climate and biogeochemical cycles on earth and how it will continue to affect them (Kiene, 1991).

The aim of this work was to evaluate the methane concentration in the water column and in pore water in a $10 \mathrm{~cm}$ sediment profile, at two sampling sites at Cabiúnas lagoon: littoral region (aquatic macrophytes stands) and limnetic region.

\section{MATERIALS AND METHODS}

Cabiúnas Lagoon is located on the Restinga de Jurubatiba National Park at Macaé in the Northern region of Rio de Janeiro State $\left(22^{\circ} 24^{\prime} \mathrm{S}\right.$ and $41^{\circ} 42^{\prime} \mathrm{W}$ ), one of the sites of the Long Term Ecological Research program (LTER) in Brazil. Cabiúnas is a shallow lagoon (mean depth of 2.37 m) and with a dendritic shape, which supports the establishment of aquatic macrophytes. The area of the lagoon is about $0.35 \mathrm{~km}^{2}$ and it has a $10 \mathrm{~km}$ perimeter (Panosso et al., 1998). The $\mathrm{pH}$ of the water is near to neutral (Petrucio, 1998).

The water and sediment samples were collected at the limnetic region (site 1) and at the littoral region (site 2) at Cabiúnas lagoon (Fig. 1), during September 2000. The littoral region was divided into three distinct sub-sites according to the macrophytes stands: Typha domingensis stand, Eleocharis interstincta stand and Potamogeton stenostachys stand.

\section{Methane Concentration Evaluation}

Five $\mathrm{mL}$ samples were collected both on the surface and on the bottom of water column, using plastic syringes and needle $(n=5)$. The samples were stored in $10 \mathrm{~mL}$ glass flasks with rubber stoppers, with $0.1 \mathrm{~mL}$ of $\mathrm{ZnCl}_{2} 4 \mathrm{M}$ to inhibit biological activity, and kept under refrigeration until the laboratory analyses.

Only the ten superficial centimeter fraction of the sediment $(0-10 \mathrm{~cm})$ was considered and it was divided at every $2 \mathrm{~cm}$. Four $\mathrm{mL}$ of each fraction from the same sampling site $(n=5)$ were stored in $25 \mathrm{~mL}$ glass flasks with rubber stoppers. To this, was added $4 \mathrm{~mL}$ of $\mathrm{NaOH}(4 \%)$ to expel the methane from the pore water (Casper, 1992). After shaking all the samples, $0.2 \mathrm{~mL}$ of gas was taken from the headspace using plastic syringes and needle and, than injected in a gas chromatograph (VARIAN Star 3400 - Varian Co., EUA). The operating conditions were FID detector temperature $220^{\circ} \mathrm{C}$, injector temperature $120^{\circ} \mathrm{C}$ and a $1 \mathrm{~m}$ Poropak-Q column (60/100 mesh) at $85^{\circ} \mathrm{C}$ and nitrogen as the carrier gas.

\section{Abiotic Variables}

The abiotic variables from water measured in the field were temperature, salinity and water conductivity using a portable salinity, conductivity and temperature analyzer (YSI model 30/10 FT). The concentration of dissolved oxygen was evaluated according to Winkler methodology, modified by Golterman et al.. (1978). The $\mathrm{pH}$ was determined using a digital pHmeter (Micronal model B278). These variables were measured both on the surface and on the bottom of water column only when it was deeper than 1 meter. 


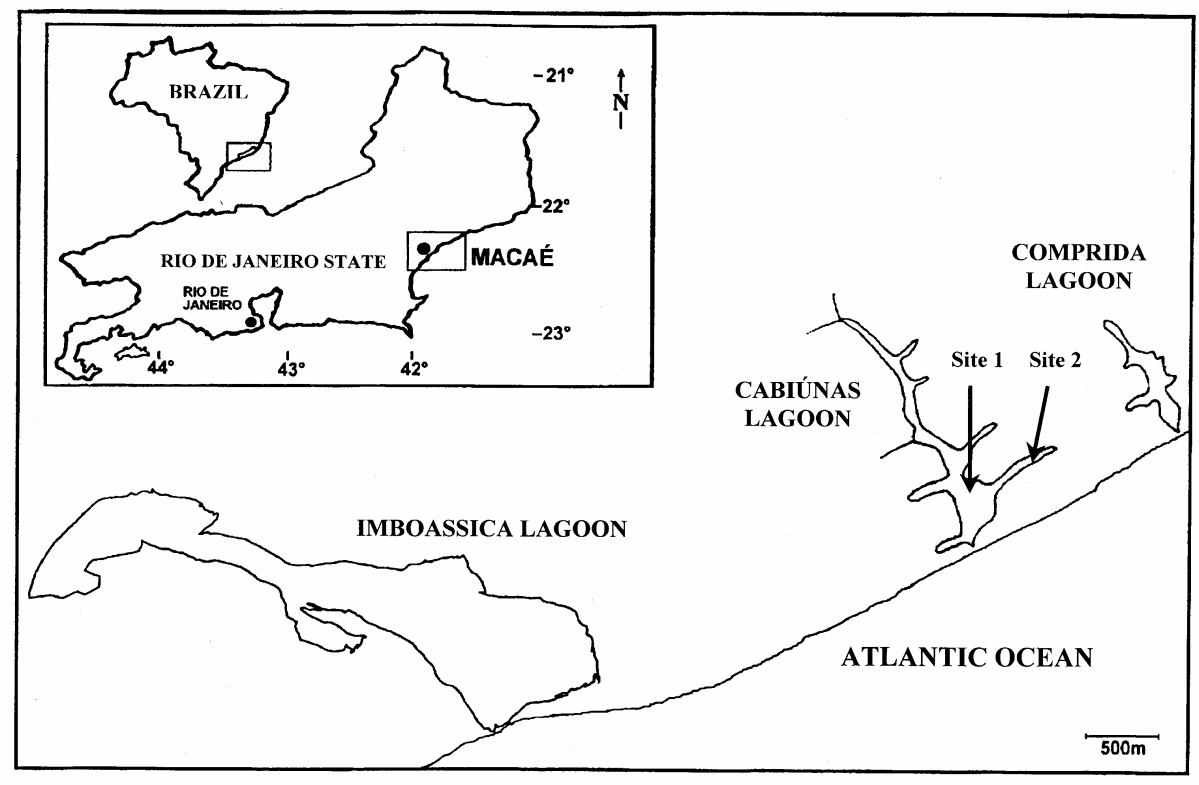

Figure 1 - Schematic localization map of Cabiúnas Lagoon. The arrows indicate the two sampling sites.

Table 1 - Abiotic variables of Cabiúnas Lagoon water column: depth, temperature, dissolved oxygen, electric conductivity, salinity and $\mathrm{pH}$.

\begin{tabular}{|c|c|c|c|c|c|}
\hline \multicolumn{2}{|c|}{ 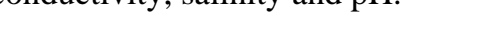 } & Limnetic region & P. stenostachys & T. domingensis & E. interstincta \\
\hline depth (m) & & 2.8 & 1.4 & 0.6 & 0.4 \\
\hline \multirow{2}{*}{ temperature $\left({ }^{\circ} \mathrm{C}\right)$} & surface & 25.2 & 26.3 & \multirow{2}{*}{25.9} & \multirow{2}{*}{26.6} \\
\hline & bottom & 25.4 & 26.4 & & \\
\hline \multirow{2}{*}{$\mathrm{O}_{2}\left(\mathrm{mg} \mathrm{L}^{-1}\right)$} & surface & 6.46 & 6.20 & \multirow{2}{*}{3.39} & \multirow{2}{*}{0.41} \\
\hline & bottom & 6.52 & 6.32 & & \\
\hline \multirow{2}{*}{ conductivity $\left(\mu \mathrm{S} \mathrm{cm}^{-1}\right)$} & surface & 610 & 578 & \multirow{2}{*}{606} & \multirow{2}{*}{491} \\
\hline & bottom & 609 & 580 & & \\
\hline \multirow{2}{*}{ salinity $(\%$ oo $)$} & surface & 0.3 & 0.3 & \multirow{2}{*}{0.3} & \multirow{2}{*}{0.2} \\
\hline & bottom & 0.3 & 0.3 & & \\
\hline \multirow{2}{*}{$\mathrm{pH}$} & surface & 7.35 & 7.30 & \multirow{2}{*}{6.68} & \multirow{2}{*}{5.99} \\
\hline & bottom & 7.20 & 7.20 & & \\
\hline
\end{tabular}

For the sediment, the same samples fractions used to determine the methane concentration were used to evaluate Kjedahl nitrogen, (Allen et al.. 1974), total phosphorus (Fassbender, 1973) and organic carbon concentrations (using a TOC-5000 Analyzer Shimadzu Co., Japan).

\section{Statistical Analysis}

The results for methane concentrations were statistically analyzed through nonparametric ANOVA with Dunn's post-hoc test. Methane concentration and organic carbon correlation was analyzed through Spearman correlation. Software GraphPad InStat 3.00 was used for all statistical analyses. The other variables were not statistically analyzed.

\section{RESULTS AND DISCUSSION}

The water column temperature varied from $25.2^{\circ} \mathrm{C}$ (limnetic region) to $26.6^{\circ} \mathrm{C}$ (E. interstincta stand). The conductivity and salinity results were similar among the sampling sites. The lower $\mathrm{pH}$ (5.99) was found in the E. interstincta stand and the 
higher (7.30) in the P. Stenostachys stand and at limnetic region. The variables measured in the field were quite similar among the sampling sites and between the surface and the bottom. These results showed the homogeneity on the water column at Cabiúnas lagoon except for the lower concentration of dissolved oxygen in the water $(0.41 \mathrm{mg} / \mathrm{L})$ registered in the region colonized by $E$. interstincta (Table 1).

The amount of nutrients (Kjedahl nitrogen, total phosphorus and organic carbon) in the sediment at the limnetic region was lower than that at the littoral region. The higher amount of nutrients was found at $T$. domingensis and E. interstincta stands, while intermediate amounts of nutrients were found in the P. stenostachys stand (Table 2).

\section{Methane Concentration in Pore Water}

The methane concentration found in the pore water at the littoral region was higher than that at the limnetic region, both at all aquatic macrophytes stands and all fractions of the sediment profile (Fig. 2). This pattern could be explained by the greater accumulation of organic matter at the littoral region, attributed to the detritus from the aquatic macrophytes and to the surrounding restinga vegetation that promoted changes in the sediment, which could facilitate methanogenesis.

Table 2 - Contents of organic carbon (C - \% DW), Kjedahl-nitrogen (N - \% DW) and total phosphorus (P - \% DW) in the sediment of Cabiúnas lagoon, (---) data not obtained.

\begin{tabular}{c|ccc|ccccccccccc}
\hline & \multicolumn{4}{|c|}{ Limnetic region } & \multicolumn{3}{c|}{ T. domingensis } & \multicolumn{3}{c|}{ E. interstincta } & \multicolumn{3}{c}{ P. stenostachys } \\
\hline fractions & $\mathrm{C}$ & $\mathrm{N}$ & $\mathrm{P}$ & $\mathrm{C}$ & $\mathrm{N}$ & $\mathrm{P}$ & $\mathrm{C}$ & $\mathrm{N}$ & $\mathrm{P}$ & $\mathrm{C}$ & $\mathrm{N}$ & $\mathrm{P}$ \\
$0-2$ & 0.71 & 0.06 & 0.00 & 12.85 & 1.64 & 0.07 & 18.20 & 2.34 & 0.06 & 7.96 & 0.50 & 0.06 \\
$2-4$ & 0.46 & 0.06 & 0.00 & 13.00 & 1.42 & 0.06 & 17.09 & 1.74 & 0.05 & 7.66 & 0.50 & 0.03 \\
$4-6$ & 0.58 & 0.15 & 0.01 & 14.63 & 1.42 & 0.06 & 15.55 & 1.35 & 0.04 & 5.48 & 0.42 & 0.02 \\
$6-8$ & 1.24 & 0.11 & 0.03 & 13.78 & 1.43 & 0.06 & 16.80 & 1.58 & 0.03 & 5.39 & 0.24 & 0.01 \\
$8-10$ & 3.37 & 0.17 & --- & 13.86 & 1.36 & 0.07 & 16.49 & 1.45 & 0.04 & 4.36 & 0.28 & 0.02 \\
\hline
\end{tabular}

On the other hand, the low organic matter deposition at the limnetic region was attributed to the low densities of phytoplankton at Cabiúnas Lagoon (Roland, 1998). Faria and Esteves (2001) studying other coastal lagoons also at northern of Rio de Janeiro State, suggested that the organic matter from the aquatic macrophytes at the littoral region was decomposed at its origin site, so when it reached the limnetic region it was more resistant for decomposition. Besides its concentration, the quality of the organic matter is another important factor to be considered (Kiene, 1991).

At the littoral region, the methane concentration in the pore water increased along the sediment profile (Fig. 2), as observed in other ecosystems (Benstead and Lloyd, 1996; Van der Nat and Middelburg, 2000). Despite this, the corresponding increase in carbon concentration along the sediment profile was not observed $(\mathrm{r}=$ $0.3985, n=20, p>0.05$ ). It can be due to the sediment structure that can support different microbial communities. In steady state, undisturbed sediments show a characteristic stratification. The availability of $\mathrm{O}_{2}$, nitrate, ferric iron and sulfate typically decreases with the distance from the anoxic-oxic interface, so that in the end there is the zone where $\mathrm{CH}_{4}$ production becomes the dominant final step in organic matter degradation (Conrad, 1989).

In relation to the methane concentration at the superficial fraction of the sediment $(0-2 \mathrm{~cm})$ (Fig. 2), only the area colonized by P. stenostachys $(3.7 \mathrm{mM})$ was significantly higher $(\mathrm{p}<0.05)$ than the limnetic region $(0.3 \mathrm{mM})$, contrary to the lower amounts of nutrients found in the sediment at this site (Table 2). According to Brum (2000) the $P$. stenostachys detritus decomposed five times faster than that observed for $E$. interstincta. According to Farjalla et al.. (1999), the emergent aquatic macrophytes $T$. domingensis and $E$. fistulosa have a potential decomposition rate slower than $P$. stenostachys, because of the high percentage of supporting tissues that are more resistant to microorganisms decomposition. Submerged aquatic macrophytes, such as $P$. stenostachys, have a great reduction in their supporting tissues, since they are sustained by the water column and by aerenchyma tissue (Esteves, 1998). It enables the release of more labile substrate that can be easily used by the microbial 
community in the water column and in the superficial fraction of the sediment, while the more refractory substrate is in the deeper layers of the sediment. It is possible that the nutrient concentration on sediment at the P. stenostachys stand was lower because of its high decomposition rate and low contribution of particulate detritus from this macrophyte species.

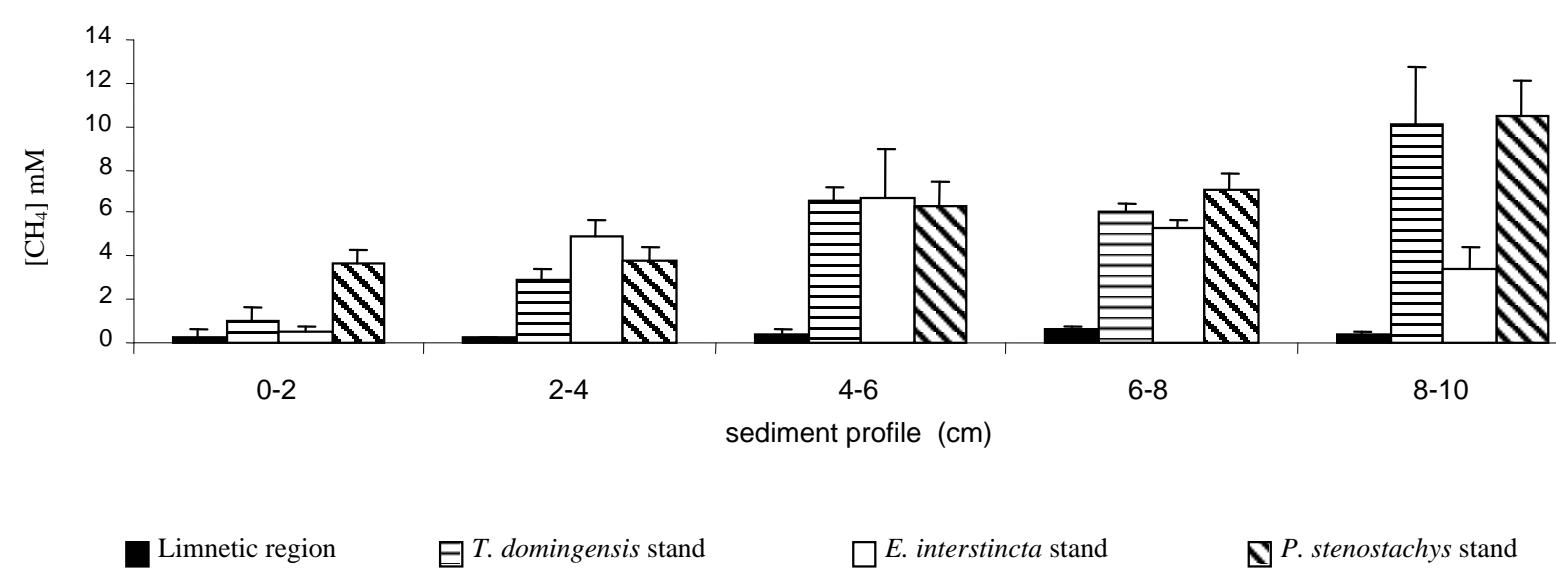

Figure 2 - Vertical concentrations profiles of pore water methane.

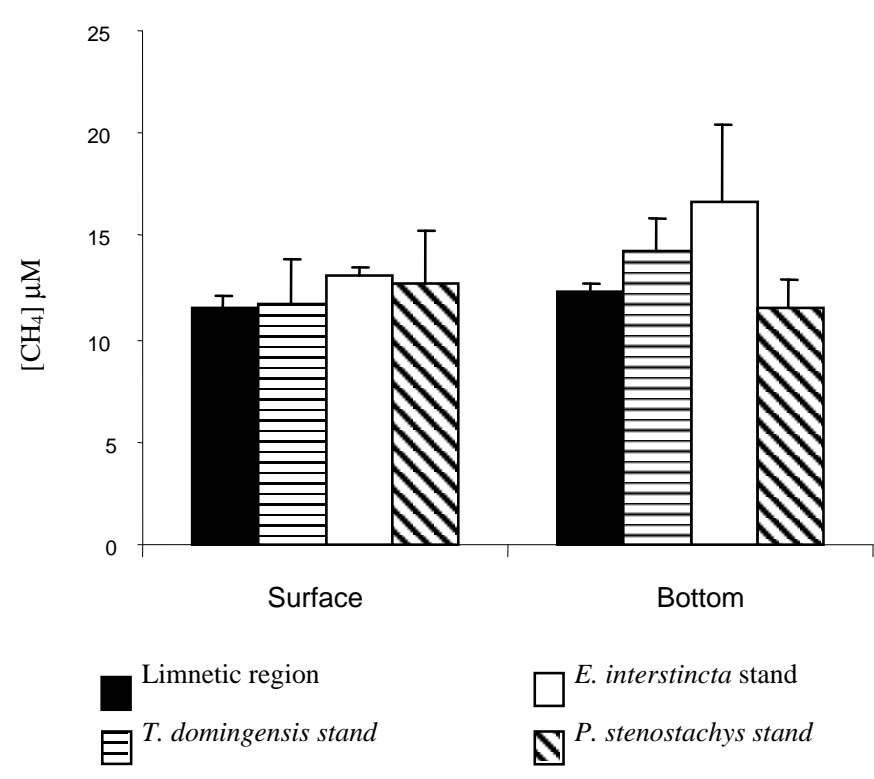

Figure 3 - Surface and bottom water column methane concentration ( $p>0.05)$.

Comparing the higher methane concentration found in the sediment at Cabiúnas lagoon to the higher concentrations found in other ecosystems, (Table 3), It was observed that the methane concentration at the limnetic region of Cabiunas lagoon was similar to irrigated rice fields in Italy, coastal basin of North Carolina (USA) and
Ellergower Moss site of New Gallowway (Scotland). However, compared to other ecosystems, the methane concentration in the sediment at the macrophytes stands at Cabiúnas lagoon (Table 3) could be considered an important site of methane production. 


\section{Methane Concentration in Water Column}

In the water column, there were no significant differences ( $>>0.05)$ among the macrophytes stands and between those and the limnetic region, both at the surface and the bottom $(p>0.05)$ (Fig. 3). Considering the influences of the pore water upon the water column through the nutrients release and gas diffusion (Fenchel et al., 1998), we could expect higher methane concentration at the littoral region of Cabiúnas lagoon. However, Cabiúnas lagoon and other shallow coastal lagoons are submitted to water mixture due to wind action that avoid water column stratification (Ecolagoas project reports, 1991-1996, unpublished data). It explained the methane concentration similarity observed both between limnetic and littoral region and between surface and bottom (Fig. 3) and, among the abiotic variables shown in Table 2.

Table 3 - Methane concentrations in water column (lowest and highest concentrations) and the highest concentrations in pore water and the respective sediment depth, (---) data not obtained.

\begin{tabular}{|c|c|c|c|c|}
\hline Location & $\begin{array}{c}{\left[\mathrm{CH}_{4}\right]} \\
\text { water }(\mu \mathrm{M})\end{array}$ & $\begin{array}{c}\text { Higher }\left[\mathrm{CH}_{4}\right] \\
\text { pore water }(\mathrm{mM})\end{array}$ & $\begin{array}{c}\text { Sediment } \\
\text { depth }(\mathrm{cm})\end{array}$ & References \\
\hline $\begin{array}{l}\text { irrigated rice fields } \\
\text { northern Italy }\end{array}$ & --- & $\sim 0.40$ & 7.0 & $\begin{array}{l}\text { Frenzel et al., } \\
1999\end{array}$ \\
\hline $\begin{array}{c}\text { coastal basin } \\
\text { North Carolina, USA }\end{array}$ & --- & $\sim 2.00$ & 10.0 & $\begin{array}{l}\text { Martens et al., } \\
\quad 1998\end{array}$ \\
\hline $\begin{array}{c}\text { Eckernforde Bay } \\
\text { Kiel Bight, Baltic Sea }\end{array}$ & --- & $\sim 7.00$ & 100.0 & $\begin{array}{l}\text { Martens et al., } \\
\quad 1998\end{array}$ \\
\hline $\begin{array}{l}\text { Ellergower Moss site } \\
\text { New Galloway, Scotland }\end{array}$ & --- & $\sim 0.35$ & 20.0 & $\begin{array}{l}\text { Benstead and } \\
\text { Lloyd, } 1996\end{array}$ \\
\hline Baltic Sea & 0.05 to 1.2 & $\sim 4.00$ & 22.5 & $\begin{array}{l}\text { Schmaljohann, } \\
1996\end{array}$ \\
\hline $\begin{array}{l}\text { Open ocean } \\
\text { surface waters }\end{array}$ & 0.0018 to 0.0031 & --- & --- & Heyer, 1990 \\
\hline $\begin{array}{c}\text { Diogo Lake } \\
\text { Open Water, São Paulo, Brazil } \\
\text { Diogo Lake }\end{array}$ & 0.73 to 1.35 & --- & --- & Ballester, 2001 \\
\hline $\begin{array}{c}\text { Macrophytes stands, São Paulo, } \\
\text { Brazil }\end{array}$ & 0.84 to 2.60 & --- & --- & Ballester, 2001 \\
\hline $\begin{array}{l}\text { Cabiúnas Lagoon } \\
\text { Limnetic region }\end{array}$ & 11.46 to 12.32 & 0.61 & $6.0-8.0$ & this research \\
\hline $\begin{array}{l}\text { Cabiúnas Lagoon } \\
\text { Littoral region }\end{array}$ & 11.43 to 16.70 & 10.52 & $8.0-10.0$ & this research \\
\hline
\end{tabular}

Compared to other ecosystems, the methane concentration found at Cabiúnas lagoon (Table 3), was at least four times higher than Diogo Lake, (SP, Brazil), about 300 times higher than the Baltic Sea and 9000 times higher than superficial oceanic waters. These results suggested that the aquatic macrophytes species studied at Cabiúnas lagoon had a positive influence on methanogenesis. However, it was not possible to evaluate the influence of these species on the methane concentration in the water column.

\section{ACKNOWLEDGEMENTS}

The authors thank CNPq and PETROBRAS for financial support to Long Term Ecological Research program (LTER) and Ecolagoas project, respectively, Adriana de Melo Rocha for improvement in English, André Luiz dos Santos Furtado and Vinicius Fortes Farjalla for revision and helpful comments.

\section{RESUMO}

O objetivo dessa pesquisa foi determinar a concentração de metano na coluna d'água e na água intersticial do sedimento nas regiões 
limnética e litorânea de uma lagoa costeira (Lagoa Cabiúnas, Macaé, RJ). Na região litorânea as amostras foram coletadas em três estandes de macrófitas (Typha domingensis, Eleocharis interstincta e Potamogeton stenostachys). A concentração de metano na água intersticial na região litorânea foi maior do que aquela encontrada na região limnética em cada fração do sedimento. A maior concentração de metano na fração superficial do sedimento $(0-2 \mathrm{~cm})$ foi observada no estande de P. stenostachys (3.7 $\mathrm{mM})$. Este resultado foi o único significativamente diferente $(\mathrm{p}<0.05)$ da região limnética. A concentração de metano na água intersticial aumentou com a profundidade nos estandes de macrófitas. A concentração de metano na coluna d'água não variou significativamente entre os pontos de coleta $(p>0.05)$. Os resultados sugerem que há uma considerável influência das macrófitas aquáticas estudadas na concentração de metano na água intersticial do sedimento.

\section{REFERENCES}

Allen, S. E.; Grimshaw, H. M.; Parkinson, J. A. and Quarmby, C. (1974), Chemical analysis of ecological material. Oxford : Blackwell Scientific Publications.

Ballester, M. V. R. and Santos, J. E. (2001), Biogenic gases $\left(\mathrm{CH}_{4}, \mathrm{CO}_{2}\right.$ and $\left.\mathrm{O}_{2}\right)$ distribution in a riverine wetland system. In: Faria, B. M.; Farjalla, V. F. and Esteves, F. A. (eds.). Oecologia Brasiliensis: Aquatic Microbial Ecology in Brazil, 9, 21-31.

Benstead, J. and Lloyd, D. (1996), Spatial and temporal variations of dissolved gases $\left(\mathrm{CH}_{4}, \mathrm{CO}_{2}\right.$ and $\left.\mathrm{O}_{2}\right)$ in peat cores. Microb. Ecol., 31, 57-66.

Boon, P. I. and Sorrel, B. K. (1995), Methane fluxes from an Australian floodplain wetland: the importance of emergent macrophytes. J. N. Am. Benthol. Soc., 14 : (4), 582-598.

Boone, D. R. (1991), Ecology of methanogenesis. In: Rogers, J. E. and Whitman, W. B. (eds.). Microbial Production and Comsumption of Greenhouse Gases: Methane, Nitrogen Oxides and Halomethanes. Washington, DC. : American Society for Microbiology. pp. 57-70.

Brum, P. R. and Esteves, F. A. (2001), Changes in abundance and biomass of the attached bacterial community throughout the decomposition of three species of aquatic macrophytes. In: Faria, B. M.; Farjalla, V. F. and Esteves, F. A. (eds.). Oecologia Brasiliensis: Aquatic Microbial Ecology in Brazil, 9, 77-95.
Casper, P. (1992), Methane production in lakes of different trophic state. Arch. Hydrobiol. Beih. Ergebn. Limnol., 37, 149-154.

Cicerone, R. J. and Oremland, R. S. (1988), Biogeochemical aspects of atmospheric methane. Global Biogeochem. Cycles, 2, 299-327.

Conrad, R. (1989), Control of methane production in terrestrial ecosystems. In: Andreae, M. O. and Schimel, D. S. (eds.). Exchange of Trace Gases Between Terrestrial Ecosystems and the Atmosphere, Wiley-Interscience, Chichester, New York, Brisbane, Toronto, Singapore. pp. 39-58.

Esteves, F. A. (1998), Fundamentos de Limnologia, $2^{\text {nd }}$ ed. Rio de Janeiro : Interciência.

Faria, B. M. and Esteves, F. A. (2001), Dissolved organic carbon in two Brazilian coastal lagoons: sources and utilization for heterotrophic bacteria. In: Faria, B. M.; Farjalla, V. F. and Esteves, F. A. (eds.). Oecologia Brasiliensis: Aquatic Microbial Ecology in Brazil, 9, 57-64.

Farjalla, V. F.; Marinho, C. C. and Esteves, F. A. (1999), Uptake of oxygen in the initial stages of decomposition of aquatic macrophytes and detritus from terrestrial vegetation in a tropical coastal lagoon. Acta Limnol. Brasil., 11 : (2), 185-193.

Fassbender, H. W. (1973), Simulate P-Bestinmung in N-Kjeldahl Ausfschlub von Bodenproben. Die Phosphörsäure, 30, 44-53.

Fenchel, T.; King, G. M. and Blackburn, T. H. (1998), Bacterial Biogeochemistry - the ecophisiology of mineral cycling. $2^{\text {nd }}$ ed. San Diego, London, Boston, New York, Sydney, Tokyo, Toronto : Academic Press.

Frenzel, P.; Bosse, U. and Janssen, P. H. (1999), Rice roots and methanogenesis in a paddy soil: ferric iron as an alternative electron acceptor in the rooted soil. Soil Biol. and Biochem., 31, 421-430.

Golterman, H. L.; Clymo, R. S. and Ohnstad, M. A. M. (1978), Methods of Physical and Chemical Analysis of Freshwaters. Oxford : Blackwell.

GraphPad Software 3.00 (1998), InStat guide to choosing and interpreting statistical tests. San Diego, California : GraphPad Software, Inc.

Heyer, J. (1990), Der Kreislauf des Methans, Berlin : Akademie-Verlag.

Jones, W. J. (1991), Diversity and physiology of methanogens. In: Rogers, J. E. and Whitman, W. B. (eds.). Microbial Production and Comsumption of Greenhouse Gases: Methane, Nitrogen Oxides and Halomethanes. Washington, DC : American Society for Microbiology. pp. 39-55.

Kiene, R. P. (1991), Production and consumption of methane in aquatic systems. In: Rogers, J. E. and Whitman, W. B. (eds.). Microbial Production and Comsumption of Greenhouse Gases: Methane, Nitrogen Oxides and Halomethanes. Washington, DC : American Society for Microbiology. pp. 111-146. 
King, G. M. (1994), Associations of methanotrophs with the roots and rhizomes of aquatic vegetation. Appl. and Environm. Microbiol., 60 : (9), 3220-3227.

Kulshreshtha, K.; Singh, S. N. and Agnihotri, S. (2000), Existence of micropores on the tiller surface of Schoenoplectus subalatus: the probable port for methane emission. Aquat. Bot., 66, 241-247.

Martens, C. S.; Albert D. B. and Alperin, M. J. (1998), Biogeochemical processes controlling methane in gassy coastal sediments - Part 1. A model coupling organic matter flux to gas production, oxidation and transport. Continental Shelf Research, 18, 1741-1770.

Neue, H. U.; Gaunt, J. L.; Wang, Z. P.; BeckerHeidmann, P. and Quijano, C. (1997), Carbon in tropical wetlands. Geoderma, 79, 163-185.

Panosso, R. F.; Attayde, J. L. and Muehe, D. (1998), Morfometria das lagoas Imboassica, Cabiúnas, Comprida e Carapebus: Implicações para seu funcionamento e manejo. In: Esteves, F. A. (ed.). Ecologia das Lagoas Costeiras do Parque Nacional da Restinga de Jurubatiba e do Município de Macaé $(R J)$. Rio de Janeiro : NUPEM/UFRJ. pp. 91-105.

Petrucio, M. M. (1998), Caracterização das lagoas Imboassica, Cabiúnas, Comprida e Carapebus a partir da temperatura, salinidade, condutividade, alcalinidade, $\mathrm{O}_{2}$ dissolvido, $\mathrm{pH}$, transparência e material e suspensão. In: Esteves, F. A. (ed.). Ecologia das Lagoas Costeiras do Parque Nacional da Restinga de Jurubatiba e do Município de Macaé $(R J)$. Rio de Janeiro : NUPEM/UFRJ. pp. 109-122.

Roland, F. (1998), Produção fitoplanctônica em diferentes classes de tamanho nas lagoas Imboassica e Cabiúnas. In: Esteves, F. A. (ed.). Ecologia das Lagoas Costeiras do Parque Nacional da Restinga de Jurubatiba e do Município de Macaé (RJ). Rio de Janeiro : NUPEM/UFRJ. pp. 159-175.

Schmaljohann, R. (1996), Methane dynamics in the sediment and water column of Kiel Harbour (Baltic Sea). Mar. Ecol. Prog. Ser., 131, 263-273.

Segers, R. and Kengen, S. W. M. (1998), Methane production as a function of anaerobic carbon mineralization: a process model. Soil Biol. Biochem., 30 : (8/9), 1107-1117.

Van Der Nat, F .J. W. A. and Middelburg, J. J. (2000), Methane emission from tidal freshwater marshes. Biogeochemistry, 49, 103-121.

Yavitt, J. B. and Knapp, A. K. (1995), Methane emission to the atmosphere through emergent cattail (Typha latifolia L.) plants. Tellus, 47B, 521-534. 